\title{
AKUNTANSI PERSPEKTIF USAHA MIKRO KECIL MENENGAH (SURVEI PADA UMKM DI KOTA MATARAM)
}

\author{
B. Anggun Hilendri Lestari \\ Fakultas Ekonomi Dan Bisnis Universitas Mataram \\ hilendria@unram.ac.id \\ Sapto Hendri BS \\ Fakultas Ekonomi Dan Bisnis Universitas Mataram \\ Saptohendri9@yahoo.com \\ L. Takdir Jumaidi \\ Fakultas Ekonomi Dan Bisnis Universitas Mataram \\ takdirjumaidi@unram.ac.id \\ D. Tialurra Della Nabila \\ Fakultas Ekonomi Dan Bisnis Universitas Mataram \\ tialurradellanabila@unram.ac.id
}

\begin{abstract}
Accounting information has an important role to achieve business success, including for small businesses. Accounting information can be a reliable basis for decision-making in managing small businesses, including market development decisions, pricing and others. The purpose of this study was to determine the perspectives of MSMEs owners about the accounting and financial management of their businesses. Based on the research results, perspective accounting MSMEs owners in the Mataram city is limited by income record and expenditure only or simple bookkkeeping. Financial management is done simply by knowing the initial capital has returned and the remaining results of operations are profit

Keywords: accounting, financial management

Abstrak

Informasi akuntansi mempunyai peran penting untuk mencapai keberhasilan usaha, termasuk bagi usaha kecil. Informasi akuntansi dapat menjadi dasar yang andal bagi pengambilan keputusan-keputusan dalam pengelolaan usaha kecil, antara lain keputusan pengembangan pasar, penetapan harga, dan lain-lain. Tujuan penelitian ini adalah untuk mengetahui perspektif para pemilik UMKM tentang akuntansi dan pengelolaan keuangan usaha mereka. Berdasarkan hasil penelitian Akuntansi perspektif para pemilik UMKM di kota mataram sebatas pada pencatatan pemasukan dan pengeluaran saja atau pembukuan sederhana.
\end{abstract}


Pengelolaan keuangan dilakukan secara sederhana dengan mengetahui modal awal sudah kembali dan sisa hasil usaha merupakan keuntungan.

\section{Kata Kunci: akuntansi, pengelolaan keuangan}

\section{PENDAHULUAN}

\section{Latar Belakang}

Pasca Gempa Bumi Lombok dan Sumbawa, perkembangan ekonomi sempat tersendat, peran usaha mikro kecil menengah (UMKM) yang sangat berperan besar dalam menyokong perekonomian daerah terdampak bencana gempa bumi beberapa bulan yang lalu. Pelaku usaha mikro, kecil dan menengah harus berusaha lebih kuat lagi dalam mengatasi masalah tersebut. Ketua Dewan Penasehat TDA Kota Mataram sekaligus Wakil Ketua Kadin NTB Bidang UMKM dan Ekonomi Kreatif, Anas Amrullah mengatakan sejak saat ini kita UMKM di NTB khususnya pulau Lombok, harus mendesain ulang bisnisnya. Begitu pula halnya dengan UMKM yang berkembang di Kota Mataram. Dinas Perindustrian, Koperasi dan UMKM Kota Mataram terus melakukan berbagai pelatihan kepada para pelaku usaha. Sementara untuk peningkatan kapasitas sumber daya manusia UMKM, pemerintah bekerja sama dengan berbagai pihak menfasilitasi pelatihan technopreneur, fasilitasi pemasaran produk UMKM melalui pengembangan teknologi digital, juga pelatihan membuat website.

Ada hal penting yang terlewati dari pengembangan yang dilakukan oleh pemerintah tersebut. Dinas Perindustrian, Koperasi dan UMKM Kota Mataram melupakan bahwa pengelolaan keuangan juga penting dalam pengembangan suatu usaha. Pengelolaan keuangan terkait dengan informasi akuntansi yang mempunyai peran penting untuk mencapai keberhasilan usaha, termasuk bagi usaha kecil (Megginson et al., 2000). Informasi akuntansi dapat menjadi dasar yang andal bagi pengambilan keputusan-keputusan dalam pengelolaan usaha kecil, antara lain keputusan pengembangan pasar, penetapan harga, dan lain-lain.

Tujuan penelitian ini adalah untuk mengetahui perspektif para pemilik UMKM tentang akuntansi dan pengelolaan keuangan usaha mereka. Berdasarkan hasil penelitian Akuntansi perspektif para pemilik UMKM di kota mataram sebatas pada pencatatan pemasukan dan pengeluaran saja atau pembukuan sederhana. Pengelolaan keuangan dilakukan secara sederhana dengan mengetahui modal awal sudah kembali sisa hasil usaha merupakan keuntungan. 


\section{TELAAH LITERATUR DAN PENGEMBANGAN HIPOTESIS}

\section{Penelitian Terdahulu}

Setyowati, 2013 meneliti tentang Pengaruh Persepsi Pengusaha Atas Informasi Akuntansi Serta Penyelenggaraan Dan Penggunaan Informasi Akuntansi Terhadap Keberhasilan UMKM (Studi Kasus Kampung Batik Laweyan Surakarta). Hasil penelitian ini membuktikan bahwa Persepsi Pengusaha atas Informasi Akuntansi berpengaruh positif dan signifikan terhadap Keberhasilan Usaha pada Kampoeng Batik Laweyan Surakarta.

Hanum, 2013 melakukan penelitian tentang Pengaruh Persepsi Pengusaha Kecil Atas Informasi Akuntansi Keuangan Terhadap Keberhasilan Perusahaan (Survei Pada Usaha-Usaha Kecil Di Kota Medan) dengan hasil penelitian menunjukkan bahwa: (1) Pembelajaran, Motivasi dan Kepribadian secara bersama-sama mempunyai pengaruh yang signifikan Persepsi Akuntansi Untuk informasi mengenai UKM di Medan. Besarnya variasi variabel persepsi informasi akuntansi yang dapat dijelaskan oleh proses pembelajaran, motivasi, dan kepribadian adalah sebesar $35,2 \%$, sisanya $64,8 \%$ tidak dijelaskan atau variabel lain berkontribusi tetapi tidak dimasukkan dalam model penelitian ini. Ini menunjukkan bahwa semakin tinggi pembelajaran, motivasi dan kepribadian bersama persepsi usaha kecil tentang informasi akuntansi akan semakin tinggi pula. (2) Proses pembelajaran tidak memiliki pengaruh pada persepsi usaha kecil tentang informasi akuntansi. Ini menunjukkan bahwa proses pembelajaran yang baik belum dapat memastikan tumbuhnya persepsi usaha kecil tentang informasi akuntansi tentang UKM di Medan. (3) Motivasi memiliki pengaruh pada persepsi usaha kecil pada informasi akuntansi. Hal ini menunjukkan bahwa pemilik usaha kecil memiliki motivasi tinggi untuk menjamin pemilik usaha kecil meningkatkan persepsi informasi akuntansi tentang UKM di Medan. (4) Kepribadian tidak memiliki pengaruh pada persepsi usaha kecil pada informasi akuntansi. Hal ini menunjukkan bahwa kepribadian yang baik belum dapat menjamin peningkatan persepsi informasi akuntansi usaha kecil tentang UKM di Medan. (5) Persepsi usaha kecil pada informasi akuntansi tidak berpengaruh pada keberhasilan bisnis. Hal ini menunjukkan bahwa persepsi usaha kecil tentang informasi akuntansi tidak mampu menjamin peningkatan keberhasilan bisnis di UKM di Medan.

Tuti, 2014 meneliti Faktor-Faktor Yang Mempengaruhi Pemahaman UMKM Dalam Menyusunan Laporan Keuangan Berdasarkan SAk ETAP, yang mana hasil penelitian membuktikan bahwa pemberian informasi dan sosialisasi, latar belakang pendidikan, tingkat pendidikan dan ukuran bisnis tidak mempengaruhi pemahaman UMKM dalam menyusun laporan keuangan berdasarkan SAK ETAP. Hanya lama usahalah yang berpengaruh signifikan pemahaman UMKM dalam menyusun laporan keuangan berdasarkan SAK ETAP. 
Anugrah, 2015 melakukan penelitian tentang Analisis Faktor - Faktor Yang Mempengaruhi Pemahaman Usaha Mikro Kecil Dan Menengah (UMKM) Dalam Penggunaan Informasi Akuntansi (Studi pada Usaha Mikro Kecil Dan Menengah Di Kabupaten Jember). Hasil penelitian menunjukkan bahwa secara simultan (bersama-sama) variabel independen berpengaruh positif dan signifikan terhadap pemahaman UMKM dalam penggunaan informasi akuntansi. Sedangkan secara parsial variabel skala usaha dan tingkat pendidikan berpengaruh positif dan signifikan terhadap pemahaman UMKM dalam penggunaan informasi akuntansi. Sedangkan untuk variabel umur perusahaan dan UMKM sebagai penerima kredit dari perbankan tidak berpengaruh positif dan signifikan terhadap pemahaman UMKM dalam penggunaan informasi akuntansi.

\section{Akuntansi dan Laporan Keuangan}

Penyelenggaraan dan Penggunaan Informasi Akuntansi Penyelenggaraan informasi akuntansi adalah pencatatan kegiatan-kegiatan usaha / transaksi ke dalam catatan-catatan akuntansi. Penggunaan informasi akuntansi adalah pemanfaatan informasi-informasi akuntansi yang berasal dari catatan-catatan akuntansi dalam pengambilan keputusan bisnis (Pinasti 2007). Akuntansi dapat didefinisikan dari berbagai aspek. Salah satu definisi yang umum dipergunakan untuk menjelaskan terminologi "akuntansi" adalah sebagaimana yang dikeluarkan oleh American Institute of Certified Public Accountant (AICPA:1930), bahwa "Akuntansi adalah suatu seni tentang pencatatan, penggolongan, dan peringkasan, dengan cara yang informatif dan bentuk uang, transaksi atau kejadian keuangan perusahaan, dan interpretasi atas hasilnya". Akuntansi berfungsi memberikan informasi kepada pihak-pihak yang berkepentingan atas aktivitas ekonomi suatu entitas. Informasi paling umum yang dihasilkan dalam proses akuntansi berwujud laporan keuangan. Laporan keuangan merupakan sarana pengkomunikasian informasi keuangan utama kepada pihak-pihak yang berkepentingan (Kieso, Weygdant \& Warfield, 2007). Sementara menurut Harahap (2000: 49) laporan keuangan merupakan hasil akhir dari proses akuntansi. Di samping itu, laporan keuangan juga dapat dipandang sebagai bentuk pertanggungjawaban manajemen. Dalam memenuhi tujuannya, laporan keuangan juga menunjukkan apa yang telah dilakukan manajemen (stewardship) atau pertanggungjawaban manajemen atas sumber daya yang dipercayakan kepadanya (IAI, 2009). Tujuan laporan keuangan sebagaimana dinyatakan dalam Standar Akuntansi Keuangan Entitas Tanpa Akuntabilitas Publik (SAK-ETAP) adalah menyediakan informasi posisi keuangan, kinerja keuangan, dan laporan arus kas suatu entitas yang bermanfaat bagi sejumlah besar pengguna dalam pengambilan keputusan ekonomi oleh siapapun yang tidak dalam posisi dapat meminta laporan keuangan khusus untuk memenuhi kebutuhan informasi tertentu. Untuk memenuhi tujuan 
tersebut maka informasi akuntansi atau laporan keuangan harus memenuhi syarat kualitatif seperti dapat dipahami, relevan, materialitas, keandalan, substansi mengungguli bentuk, pertimbangan sehat, kelengkapan, dapat dibandingkan, tepat waktu dan keseimbangan antara biaya dan manfaat.

\section{Akuntansi dan Perilaku}

Akuntansi merupakan alat, dimana pemanfaatanya akan sangat bergantung pada individu penggunanya. Seperti yang diketahui bahwa individu bersifat unik. Masing-masing individu memiliki persepsi dan pandangan yang beragam terkait satu permasalahan. Demikian pula dalam praktik akuntansi, masing-masing individu yang terlibat dalam praktik tersebut memiliki preferensi dan persepsi yang beragam. Pandangan terebut terbentuk dari berbagai aspek, misalnya pendidikan, kultur budaya bahkan interaksi dengan masyarakat sekitar. Untuk itu, penelitian ini mengambil beberapa teori terkait pembentukan pola pikir dan preferensi untuk memperoleh landasan yang cukup terkait persepsi manajemen terhadap praktik akuntansi (Pinasti, 2007).

\section{Definisi Usaha Mikro Kecil Menengah (UMKM)}

Usaha Mikro Kecil dan Menengah (UMKM) memiliki definisi yang berbeda pada setiap literatur menurut beberapa instansi atau lembaga bahkan undang-undang. Sesuai dengan Undang-Undang nomor 20 tahun 2008 tentang Usaha Mikro Kecil dan Menengah, UMKM didefinisikan sebagai berikut:

a. Usaha Mikro adalah usaha yang memenuhi kriteria usaha mikro dengan nilai kekayaan bersih tidak lebih dari Rp 50.000.000 tidak termasuk tanah dan tempat bangunan usaha atau memiliki hasil penjulan tahunan tidak lebih dari Rp. 300.000.000.

b. Usaha Kecil adalah usaha yang memenuhi kriteria usaha kecil dengan nilai kekayaan bersih lebih dari Rp 50.000 .000 sampai dengan yang paling banyak Rp 500.000.000 tidak termasuk tanah dan tempat bangunan usaha atau memiliki hasil penjulan tahunan lebih dari Rp. 300.000.000 sampai yang terbanyak Rp 2.500.0000.000.

c. Usaha Menengah adalah usaha yang memenuhi kriteria usaha besar dengan kekayaan bersih lebih dari Rp 500.000.000 sampai dengan paling banyak Rp 10.000.000.000 tidak termasuk tanah dan tempat bangunan usaha atau memiliki jumlah penjualan tahunan sebesar Rp 2.500.000.000 sampai dengan paling banyak Rp. 50.000.000.000. 


\section{METODE PENELITIAN}

1. Jenis penelitian ini adalah penelitian deskriptif yang berusaha mendeskripsikan persepsi para pemilik UMKM di Kota Mataram tentang akuntansi melalui pendekatan survei.

2. Penelitian ini dilaksanakan secara terpusat di Kota Mataram.

3. Populasi sekaligus sampel dalam penelitian ini adalah UMKM di Kota Mataram.

4. Waktu penelitian dilaksanakan dari bulan Mei sampai bulan Oktober tahun 2019, dengan pengumpulan data lapangan pada bulan Juli dan Agustus 2019.

5. Sumber data penelitian ini adalah data sekunder berupa data terkait UMKM dan data primer yang diperoleh dari jawaban kuesioner yang diberikan kepada para pemilik UMKM berisi: (1) data pemilik: nama, alamat kontak dan sebagainya, (2) lamanya usaha (3) respon pemilik terkait pengelolaan keuangan yang dilakukan (4) pentingnya informasi akuntansi (5) preferensi pemilik UMKM untuk menyusun laporan keuangan usahanya.

6. Teknik pengumpulan data dilakukan dengan dokumentasi, wawancara, dan pemberian kuesioner kepada pemilik UMKM dengan pengisisan langsung oleh responden.

7. Proses penelitian dilakukan dengan empat tahap: 1) Tahap perencanaan dan persiapan, 2) Tahap pelaksanaan, 3) Tahap pengolahan data, 4) Tahap analisis data, dan yang terakhir 5) Tahap pelaporan.

\section{HASIL DAN PEMBAHASAN}

Hasil penelitian menjelaskan bahwa 14 dari 17 atau 82\% dari responden belum menerapkan akuntansi dalam pengelolaan keuangan mereka. Hal tersebut disebabkan antara lain: 1) penerapan akuntansi membutuhkan biaya lebih, 2) akuntansi sulit dan rumit, 3) tidak ada karyawan yang memahami akuntansi, 4) Pendapatan yang diperoleh tidak setiap hari. Meskipun begitu terdapat 3 atau $18 \%$ responden yang menurut mereka sudah menerapkan akuntansi karena bagi mereka menyusun laporan keuangan itu penting untuk mengetahui perkembangan usaha mereka. Padahal akuntansi yang mereka maksud adalah pembukuan sederhana secara manual. UMKM hanya mencatat pemasukan dan pengeluaran uang saja tidak didasari Standar Akuntansi Keuangan (SAK) Entitas Mikro Kecil Menengah (EMKM), sehingga komponen laporan keuangan tidak lengkap. Meskipun ada 1 UMKM yang menggunakan MS.Excel dalam menyusun laporan keuangannya. Hal tersebut menunjukkan UMKM belum memanfaatkan aplikasi akuntansi. 


\section{SIMPULAN}

Adapun kesimpulan dari penelitian ini adalah sebagai berikut: 1) Akuntansi perspektif para pemilik UMKM di kota mataram sebatas pada pencatatan pemasukan dan pengeluaran saja atau pembukuan sederhana, 2) Pengelolaan keuangan dilakukan secara sederhana dengan mengetahui modal awal sudah kembali sisa hasil usaha merupakan keuntungan. Oleh karena itu perlu kiranya bagi Pemerintah daerah kota mataram melalui Dinas Perindustrian, Koperasi, dan UMKM membuat program pelatihan akuntansi dalam upaya peningkatan pengelolaan keuangan UMKM sehingga para pemilik UMKM mampu menyususn laporan keuangan dengan baik yang nantinya dapat memberikan gambaran perkembangan usaha mereka. Begitu pula dengan para pemilik UMKM agar lebih giat lagi untuk mengikuti diklat-diklat yang diselenggarakan oleh Dinas Perindustrian, Koperasi, dan UMKM selain khususnya diklat yang berkaitan dengan akuntansi untuk menambah wawasan juga sebagai upaya peningkatan pengelolaan keuangan usaha.

\section{DAFTAR PUSTAKA}

Anugrah, Yuli Dwi Yusrani. 2015. Analisis Faktor - Faktor Yang Mempengaruhi Pemahaman Usaha Mikro Kecil Dan Menengah (Umkm) Dalam Penggunaan Informasi Akuntansi (Studi pada Usaha Mikro Kecil dan Menengah di Kabupaten Jember). Skripsi. Fakultas Ekonomi Universitas Muhammadiyah Jember

Belkaoui, A. R. 2000. Teori Akuntansi. Edisi Pertama. Jakarta: Salemba Empat.

Hanum, Zulia. 2013. Pengaruh Persepsi Pengusaha Kecil Atas Informasi Akuntansi Keuangan Terhadap Keberhasilan Perusahaan (Survei Pada Usaha-Usaha Kecil Di Kota Medan). Jurnal Riset Akuntansi Bisnis, ISSN : 1693-7597, vol No. 2 September 2013

Ikatan Akuntan Indonesia. 2009. Standar Akuntansi Keuangan Entitas Tanpa Akuntabilitas Publik. Jakarta.

Kieso, Donald E., Jerry J. Weygandt, dan Terry D. Warfield, 2007. Akuntansi Intermediete, Terjemahan Emil Salim, Jilid 1, Edisi Kesepuluh, Penerbit Erlangga: Jakarta

Lensa NTB. 2018. Peran UMKM Dalam Membangun Perekonomian NTB Pasca Bencana.http://lensantb.com/2018/12. Diunduh hari rabu 20/2/2019 pukul15.45

Lombok Post. 2018. Pelaku UMKM di NTB Butuh Sentuhan Teknologi. http://lombokpost.net/2018/11/29/pelaku.Diunduh hari rabu 20/2/2019 pukul15.51

Megginson, W. L., M. J. Byrd, dan L. C. Megginson. 2000. Small Business Management: An Entrepreneur's Guidebook. Boston: Third Ed. Irwin McGraw-Hill. 
Pinasti, M. 2001. Penggunaan Informasi Akuntansi dalam Pengelolaan Usaha Para Pedagang Kecil di Pasar Tradisional Kabupaten Banyumas. Jurnal Ekonomi, Bisnis dan Akuntansi No. 1/Vol. 3/Mei.

Pinasti, M. 2007. Pengaruh penyelenggaraan dan penggunaan informasi akuntansi terhadap persepsi pengusaha kecil atas informasi akuntansi: suatu riset eksperimen. Jurnal Riset Akuntansi Indonesia. Vol.10 No.3 (September): 321-331.

Rudiantoro, R., dan S. V. Siregar. 2011. Kualitas Laporan Keuangan UMKM serta Prospek Implementasi SAK ETAP. Simposium Nasional Akuntansi XVI. Aceh. 21-22 Juli.

Setyowati, Eka. 2013. Pengaruh Persepsi Pengusaha Atas Informasi Akuntansi Serta Penyelenggaraan Dan Penggunaan Informasi Akuntansi Terhadap Keberhasilan UMKM (Studi Kasus Kampung Batik Laweyan Surakarta). Naskah Publikasi. Program Studi Akuntansi Fakultas Ekonomi Dan Bisnis Universitas Muhammadiyah Surakarta

Suhairi, Sofri Yahya \& Hasnah Haron. 2004. Pengaruh Pengetahuan Akuntansi Dan Kepribadian Wirausaha Terhadap Penggunaan Informasi Akuntansi Dalam Pengambilan Keputusan Investasi. Makalah Simposium Nasional Akuntansi VII. Denpasar.

Susanto, Y. K. 2008. Partisipasi anggaran, ketidakpastian tugas, penggunaan informasi akuntansi untuk evaluasi kinerja dan perilaku managerial. Jurnal Akuntansi dan Keuangan Indonesia. Vol.5 No.1.

Tuti, Rias. 2014. Faktor-Faktor Yang Mempengaruhi Pemahaman UMKM Dalam Menyusunan Laporan Keuangan Berdasarkan SAK ETAP. The 7th NCFB and Doctoral Colloquium 2014 Towards a New Indonesia Business Architecture Sub Tema: "Business and Economic Transformation Towards AEC 2015"ISSN NO: 1978 - 6522. Fakultas Bisnis dan Pascasarjana UKWMS

Undang-Undang Nomor 20 Tahun 2008 tentang Usaha Mikro, Kecil dan Menengah.

Wahyudi, M. 2009. Analisis faktor-faktor yang memengaruhi penggunaan informasi akuntansi pada usaha kecil dan menengah (UKM) di Yogyakarta. Tesis.Program Pascasarjana Universitas Diponegoro. 